This is the author(s) personal version of the manuscript, as accepted after the review process but prior to final layout and copyediting by the publisher. The final version will be published as:

Vaara, E. \& Whittle, A. (forthcoming). Common Sense, New Sense or NonSense? A Critical Discursive Perspective on Power in Collective

Sensemaking. Forthcoming in Journal of Management Studies. Readers are kindly asked to use the official publication in references.

\title{
COMMON SENSE, NEW SENSE OR NON-SENSE? A CRITICAL DISCURSIVE PERSPECTIVE ON POWER IN COLLECTIVE SENSEMAKING ${ }^{1}$
}

\begin{abstract}
Despite a growing interest in power in sensemaking, our understanding of how power is linked with language is still theoretically underdeveloped. To this end, we develop a critical discursive perspective on sensemaking comprised of a three-part theoretical framework that elucidates the discursive underpinnings of power in organisational sensemaking. We first explain how discursive practices are used to turn cues into meaning. We then conceptualize how power operates within three layers of discursive practices: discursive strategies, genres, and discourses. This leads us to explain how the resulting sense can be conceptualized as common sense, new sense, or non-sense. The main contribution of this paper is to help us understand how discursive practices underpin the operation of power in organisational sensemaking, thus adding a missing piece to sensemaking research. Our discursive analysis also advances understanding of the role of language in sensemaking more generally, has methodological implications for sensemaking research, and helps to move critical discourse studies forward in organisational contexts.
\end{abstract}

\footnotetext{
${ }^{1}$ We are very grateful for the constructive comments and guidance of the Editor Caroline Gatrell and the insightful comments by the three anonymous reviewers. We would also like to acknowledge the help we have received from Stewart Clegg and Ruth Wodak in developing our ideas and the framework. In addition, we wish to thank colleagues at Cardiff, Newcastle, Aalto and Oxford for comments and support in developing this paper.
} 
Common sense, new sense or non-sense? A critical discursive perspective on power in collective sensemaking

Key words: critical discourse studies, discursive practices, framing, power, sensemaking. 


\section{INTRODUCTION}

In recent years, we have seen increasing calls to bring power into sensemaking research (Maitlis and Christianson, 2014; Weick, Sutcliffe and Obstfeld, 2005). Although explicit analyses of power are still rare, important advances have been made in specific areas. Research on sensegiving has examined how actors exercise power when they attempt to influence the sensemaking of others (Gioia and Chittipeddi, 1991; Maitlis, 2004; Maitlis and Lawrence, 2007). Scholars have also used a sensemaking lens to examine power and politics in organisational change (Brown and Humphreys, 2003; Clark and Geppert, 2011) and how sense is made in public inquiries (Brown, 2004, 2005; Gephart, 1993). Others have developed a 'critical sensemaking' perspective that helps us to understand how inequality and exploitation are perpetuated or challenged (Aromaa et al, 2018; Helms Mills, Thurlow and Mills, 2010). In particular, Schildt et al. (2020) have recently offered a view that illuminates how power works in sensemaking processes in more visible or hidden ways. This view highlights the need to understand power both in its 'episodic' form, when overt struggle between actors and groups occurs during periods of overt conflict, and its 'systemic' form, in which overt struggle is precluded because particular forms of knowledge and systems of ideas are taken for granted.

What is lacking in this body of work is, however, in-depth understanding of how power is linked with the use of language that lies at the very heart of sensemaking. In this paper we follow suggestions to focus on discourse to understand how power operates in and through language in sensemaking (Brown et al, 2014; Maitlis and Christianson, 2014; Weick, 2001). While there are alternative discursive theories and methods (Phillips and Oswick, 2012), we argue that Critical Discourse Studies (CDS) offer a fruitful avenue for elucidating the role of power in sensemaking. By CDS, we refer to perspectives that share a concern with the role of discourse in the structuring of relations of power, domination, and control (van Dijk, 1998; Fairclough, 2010; Forchtner \& Wodak, 2018; Wodak and Meyer, 2015). 
In this paper, we develop a three-part theoretical framework that elucidates the discursive underpinnings of power in sensemaking. We first point to cues as the 'raw material' of sensemaking, highlighting the linkage to the discursive practices used to turn these cues into meaning. We then explain how power operates at three progressively more 'hidden' levels of analysis or 'layers': discursive strategies, genres and discourses. The first layer deals with actors and their discursive strategies, the second layer involves the genres that enable and constrain sensemaking, and the third layer deals with the discourses and their associated ideologies that are the basis on which sensemaking is established. We then argue that the resulting 'sense' that emerges from the discursive construction can be conceptualized as common sense, new sense, or non-sense, thereby capturing the dynamics of stability and change in power relations.

The main contribution of this paper is that our framework helps to understand how discursive practices serve as central elements in the operation of power in sensemaking. In particular, we offer a comprehensive framework that helps to comprehend how common sense, new sense or non-sense emerge from discursive sensemaking. In so doing, we add to the recent contribution of Schildt et al. (2020) in theorizing power in its 'systemic' form, involving taken for granted ways of seeing and acting, which they argue is a less visible but more insidious form of power than visible acts of manipulation. By highlighting the latent role of discourse in sensemaking, our analysis also answers calls to better understand the role of language in sensemaking more generally (Maitlis and Christianson, 2014). In addition, our framework gives rise to methodological ideas that can advance our understanding of discursive power in sensemaking. Finally, our analysis also offers theoretical and methodological points that help to connect insights of critical discourse studies to organisational analysis more generally.

\section{PRIOR RESEARCH ON POWER IN SENSEMAKING}


There is "no single agreed definition of "sensemaking"" (Brown et al., 2014: 266) and the field is facing a struggle in defining what sensemaking is and what scholars of sensemaking should focus on (Tsoukas et al, 2020). Conventionally, the focus has been on the cognitive processes of meaning-making embedded in group interaction (Weick, 1995, 2001). However, new developments within sensemaking research have highlighted the need to focus more attention on the social, cultural, and institutional embeddedness of sensemaking (Tsoukas et al, 2020). This stream of work has also included an effort to focus on the more mundane and taken for granted aspects of sensemaking (Holt and Cornelissen, 2014; Introna, 2019; Maitlis and Sonenshein, 2010; Patriotta, 2016; Sandberg and Tsoukas, 2015; Schildt et al., 2020). These new perspectives are important for our purposes because they highlight a movement away from the cognitivist tradition toward a conceptualization of sensemaking as activity that is linked with social structures, processes, and practices. Thus, we join this trajectory of work to broaden and deepen the scope of sensemaking research by focusing on discursive power in sensemaking.

What does existing research tell us about power in sensemaking? Three main bodies of work can be identified from extant literature: research on influence exercised in sensegiving, studies of sensemaking processes focusing on organisational change, and analysis of societal sensemaking concentrating on wider power implications. The first and most substantial body of literature has studied how actors attempt to influence the sensemaking of others, especially through 'sensegiving' (Balogun, Bartunek and Do, 2015; Gioia and Chittipeddi, 1991; Maitlis and Lawrence, 2007; Mantere et al, 2012; Pratt, 2000; Rouleau, 2005). This body of work has been linked with research on topics such as impression management and issue selling (Dutton and Duncan, 1987; Dutton and Ashford, 1993; Dutton et al., 2001). It was, however, the work by Gioia and Chittipeddi (1991) on strategic change in a university that helped to coin the term 'sensegiving' and triggered a proliferation of research on this theme. From this perspective, to 'give sense' involves the imposition of a preferred meaning-system on others to make them think 
and behave in ways that further particular ends (Vlaar, Van den Bosch and Volberda, 2006). While formal positions of power in organisational hierarchies and networks are known to be an important factor in the ability to influence or impose sense upon others (Ibarra and Andrews, 1993; Maitlis and Lawrence, 2007), studies have also shown that sensegiving can transcend such positions when other actors exercise influence (Rouleau and Balogun, 2011). Sometimes this can lead to overt struggles in the framing process which have been referred to as 'framing contests' (Kaplan, 2008).

Importantly for our purposes here, scholars have started to acknowledge the role of discourse in sensegiving (Balogun et al, 2015; Balogun and Johnson, 2004; Rouleau, 2005; Rouleau and Balogun, 2011). Maitlis and Sonenshein (2010: 572) have argued that a 'strong discursive ability' is important in shaping which account comes to dominate. Others have pointed to the behind-the-scenes political activity involved in setting the scene before the discursive competencies involved in sensegiving come into play (Rouleau and Balogun, 2011). Still others have elaborated on how sensegiving involves power when actors engage in sense 'breaking' directed at changing previous conceptions (Mantere et al., 2012), sense 'hiding' when actors hide their ways of making sense (Monin et., 2013), or sense 'censoring' when actors censor their sensemaking to conform those in positions of power (Whittle et al., 2016).

Relatedly, a stream of research has emerged on the linguistic tools used in sensemaking, such as metaphors and analogies. These studies have shown that metaphors are far from neutral cognitive tools used to render the unfamiliar more familiar. Power enters the analysis in this body of work primarily through its focus on how metaphors, as sensemaking devices, serve to preserve or disrupt existing power structures by legitimating or delegitimating the actions of organisations. For example, Patriotta and Brown (2011) show how metaphors used by students when preparing for an evaluation of their performance sought to make sense of the asymmetrical power relationships between examiner and examined, but crucially in ways that served to maintain the status quo of the power structures. Tourish and Hargie (2012) demonstrate how metaphors used 
by bankers held accountable for their role in the financial crisis serve to deflect blame not only from individuals but also from critique of the financial system itself, performing a framing function that sought to protect the status quo and maintain existing social structures. Budd et al. (2019) in turn highlight the role of metaphors in delegitimation, showing the ideological effects of how moral panics are constructed through metaphors by building on critical approaches to metaphor analysis.

A second body of literature has focused on how power and politics play out in sensemaking processes - usually in the context of organisational change (Brown and Humphreys, 2003; Clark and Geppert, 2011; Dörrenbächer and Geppert, 2006; Rouleau, 2005; Vaara, 2003). This body of work has often used sensemaking as an umbrella term without other explicit linkages to the sensemaking vocabulary. Brown and Humphreys (2003) have viewed sensemaking processes as a key part of the micro-political behavior of actors during periods of organisational change, Vaara (2003) has shown how sensemaking is a key part of post-merger organisational politics, and Huzzard (2004) and Rouleau (2005) have highlighted the role of power and politics in shaping how sense is made from, or given to, organisational change. Central to this body of work is the recognition that, as Marshall and Rollinson (2004: 74) point out, "sensemaking and power relations are closely connected" because sensemaking is invariably caught up with the political "struggles over the appropriation and fixing of meaning" (ibid.) that take place within organisations. Within this body of work, research on power and politics in the context of multinational corporations (MNCs) stands out because of the explicit linkages made between power and sensemaking (Balogun, Jarzabkowski and Vaara, 2011; Dörrenbächer and Geppert, 2006, 2011; Geppert, Becker-Ritterspach and Mudambi, 2016).

While explicit analyses of power in sensemaking processes have been rare, Schildt et al. (2020) have recently sought to differentiate between the forms of power that operate in sensemaking. The authors noted the need to move beyond 'episodic' conceptions of power to 
appreciate power in its 'systemic' form in organisational change. They propose that power in its 'systemic' form, as the taken for granted knowledge structures and identities which "shape the way actors see the world and act" (Schildt et al., 2020: 242), is both more subtle and more insidious than 'episodic' power, referring to explicit attempts to coerce or manipulate others during particular 'episodes' of social conflict. On this basis, they theorize how power is linked with automatic (preconscious and committed), improvisational (preconscious and provisional), algorithmic (conscious and committed) and reflective (conscious and provisional) sensemaking.

A third body of literature has focused on sensemaking at the societal level. This includes research on institutions such as courts and inquiries that serve to make sense of major events in society (Brown, 2000, 2004, 2005; Brown and Jones, 2000; Gephart, 1984, 1993). In an early contribution, Gephart (1984) developed a 'political sensemaking' perspective and showed how sensemaking about environmental disasters served political ends, notably through the 'normalization' of issues such as pollution. Others have later demonstrated that sensemaking serves political ends by seeking to deflect critique following disasters and accidents, thereby sustaining the status quo, and deflecting blame from the institutions involved (Gephart, 1993; Zilber, 2007; Boudes and Laroche, 2009). Brown's work on sensemaking in public inquiries and other contexts has produced important advances in the understanding of how specific accounts are privileged over others and power relations are reproduced (Brown, 2000, 2004, 2005; Brown and Jones, 2000). Others have examined how the "politics of meaning" (Patriotta, 2003: 350) involve the production of dominant narratives that systematically de-politicize problematic organisational events and justify the decisions of elite policymakers (Abolafia, 2010).

A related body of work has examined sensemaking at a higher level of analysis that includes the relationship between sensemaking and the wider social, cultural, and institutional context. Fiss and Hirsch's (2005) study explores how the discursive frames used to make sense of globalization serve to further political interests by opening up some opportunities for meaning creation while 
simultaneously closing others down. Reinecke and Ansari (2015) show that sensemaking is central to the way in which organisations answer ethical questions concerning their responsibilities to wider society and the natural environment not only through individual cognition but also through the frames that come to dominate at field level. Scholars have also asked how sensemaking is both enabled and constrained by cultural 'schemes' (Malsch, Tremblay and Gendron, 2012) or 'episteme' (O’Leary and Chia, 2007).

Finally, a related stream of research has emerged under the label 'critical sensemaking' (Aromaa et al, 2018; Helms Mills, 2003; Mills, 2008; Helms Mills et al., 2010). These studies have sought to understand the relationship between sensemaking and broader structures of inequality, domination, and exploitation (O'Connell and Mills, 2003; Mills and Helms Mills, 2004). As Helms Mills and Mills (2000) point out, while everyone might be able to make sense, not everyone has an equal chance of getting their version accepted and some people's 'sense' invariably counts more than others. For example, the critical sensemaking perspective has illuminated how gender discrimination is perpetuated and legitimated through gendered discourses that shape how we make sense of what is 'right' and 'proper' for men and women in the workplace (Helms Mills, 2005; Mills, 2002; Mills, 2006).

Where does this existing knowledge from extant research leave us in theorizing the relationship between sensemaking and power? First, with some important exceptions (Helms Mills, 2003; Schildt et al., 2020), power has tended to remain implicit in this literature, typically featuring as one of the many aspects of the social context in which sensemaking takes place rather than an explicit focus of analysis. Second, the use of an individualistic actor-centric conception of power, whereby power is understood as the ability of one actor to influence or control another actor, has significant limitations in advancing beyond 'surface mechanisms' (Willmott, 2013: 281) towards considering the deeper structures and practices through which power is enacted and 
naturalized. Third and finally, we are still lacking integrative frameworks that would elucidate how different aspects of discourse and power operate in the sensemaking process.

\section{A CDS PERSPECTIVE ON POWER}

Our starting point is a dynamic and multifaceted view of power (Clegg, 1989; Clegg et al., 2006, 2014; Fleming and Spicer, 2014). In this view, power is not a 'possession' - something that an actor can "have" or "own". Rather, power is a dynamic phenomenon because it manifests itself in processes that reconstruct social relations between actors (Foucault, 1980; Fleming and Spicer, 2014). This view of power resonates with the classic work of Lukes (1974), Foucault (1980) and Clegg (1989) in that it is not only a matter of one actor getting another to do something they would rather not do in situations of overt conflict or struggle (Dahl, 1957). It also includes the more 'systemic' power that occurs when conflict is suppressed and existing power structures are viewed as legitimate (Willmott, 2013; Fleming and Spicer, 2014).

More specifically, we propose that Critical discourse studies (CDS) offer a particularly fruitful perspective for the analysis of power for two reasons. First, CDS enable us to examine the various discursive processes, practices, and strategies in an in-depth manner, often drawing from linguistic theories and methods (Fairclough, 1989; Wodak and Meyer, 2015). Second, as the term 'critical' implies, CDS focus on power relations, structures of domination, and other issues involved in the exercise of power (Fairclough, 1989, 2010; Forchtner \& Wodak, 2018).

Critical discourse studies (CDS) originate from the work conducted in critical linguistics in the 1970s and has thereafter become known under the label CDS (Wodak and Meyer, 2015). Fairclough's influential early work on Critical Discourse Analysis (CDA) $(1989,2003,2010)$ has been highly influential, but there are other related perspectives such as the discourse-historical perspective (Reisigl and Wodak, 2015), the multimodality perspective (Kress and van Leeuwen, 2001; Van Leeuwen, 2008) and studies of discourse and ideology (van Dijk, 1998) that provide 
relevant bases for the analysis of power. To understand key aspects of CDS, it is useful to emphasize the key role of discourses as the building blocks of the social construction of reality (van Dijk, 1998; Fairclough, 2003). In sensemaking terms, available discourses enable or constrain specific actors when they make sense of social or organisational phenomena. However, actors can also purposefully mobilize particular discourses for their own advantage. This does not imply a simplistic position on intentionality, given the dual role of discourses as systems of thought that enable and constrain actors and discourses as tools or devices that people use to accomplish social actions (Alvesson and Karreman, 2000, 2011). Rather, it means appreciating the constant struggle of agency and constraint in discursive practices (Fairclough, 2010).

A key objective in CDS is to unravel both overt power struggles between social groups and also how power relation can pass unnoticed, for example through taken for granted assumptions (Fairclough \& Wodak, 1997). The concept of ideology is central to CDS because it seeks to understand how discourses mobilize specific value-laden standpoints and moral assumptions that benefit certain social groups and disadvantage others (van Dijk, 1998). From a CDS perspective, we can observe these ideological processes in any kind of talk or text, covering various genres of social interaction - ranging from published documents to spoken conversations to social media interactions - and involving multiple modes of semiosis including visuality and multimodality (Fairclough, 2003; Van Leeuwen, 2008). Unlike some other more abstract forms of discourse analysis less concerned with actual practices of talking or writing (hereafter 'texts'), CDS combine a focus both on the micro-level empirical analysis of texts with a broader focus on how these texts contribute to the reproduction or transformation of macro-level social structures (Wodak \& Meyer, 2015; Wodak \& Krzyzanowski, 2008). Thus, CDS allow one to focus on concrete acts of talking or writing as sites of ideological struggle. 


\section{A CRITICAL DISCURSIVE FRAMEWORK FOR CONCEPTUALIZING OF POWER IN SENSEMAKING}

In what follows, we will outline a three-part theoretical framework that elucidates the discursive underpinnings of power in sensemaking. Figure 1 below offers a graphical summary of the model and Tables 1 and 2 elaborate the key characteristics of our conceptual building blocks.

---Insert Figure 1 and Tables 1 and 2 here---

\section{Linkage of Cues and Discourses}

The concept of 'cue' is commonly used in sensemaking to describe the 'raw material' upon which sense is made. Cues can be anything a person can perceive with their senses, for example something we hear, see, touch, taste, or smell. Cues do not arrive pre-packaged and ready-made as meaningful elements upon which we then act. Rather, as Weick, Sutcliffe and Obstfeld (2005) observe, citing Chia (2000: 517), the "undifferentiated flux of raw experience" has to have certain elements "forcibly carved out" for attention. Maitlis and Sonenshein (2010: 551-2) describe this process as involving the "bracketing of cues from the environment" based on their interpretation using "salient frames".

While a discursive perspective such as the one taken here is obviously interested in the texts we read and utterances we hear, the 'raw materials' of discursive sensemaking can also be multimodal and include elements such as images, colour, music and even smell (Kress and van Leeuwen, 2001; Van Leeuwen, 2008; Hollerer et al, 2019). In this view, sensemaking is fully 'embodied' in that all manner of "bodily senses and feelings" are involved, not just what we see or hear (Meziani and Cabantous, 2020: 1387). The important point for our purposes here is that language furnishes us with the categories and meaning systems through which a selection of these embodied cues is turned into shared meanings. 
Given the active role played by frames in the sensemaking process, cues only have meaning when they are extracted and interpreted as part of the process of asking "what is going on here?" (Weick, Sutcliffe and Obstfeld, 2005: 410). The terms "extracted cue" (Weick, Sutcliffe and Obstfeld, 2005: 414) and "salient cues" (Weick, 2001: 462) help to understand that only some cues will be extracted from the perceptual environment because they have salience within the frame provided by the discursive practices used. Figure 1 captures this process using by depicting how discursive practices shape which cues are 'bracketed in' for attention and which are 'bracketed out' and not attended to.

We follow Glynn and Watkiss (2020: 1343) in viewing language and discourse as critical to the sensemaking process because "discourse provides the social mechanism through which meanings are enacted". This discourse, as spoken language or a written text, provides shared 'mental models' or 'cognitive representations' (Glynn \& Watkiss, 2020: 1338) upon which we can collectively act. This discourse could be something as simple as a shared metaphor or something as complex as a shared storyline (ibid: 1343). As such, discourses are both the "ingredients" and "products" of sensemaking (ibid: 1343), as captured by the 'loop' or 'cycle' in Figure 1. We come back to this feedback loop and bracketing aspect later in our discussion of the recursive role of new sense, common sense, and non-sense in informing the next cycle of sensemaking.

\section{'Layers' of Discursive Power}

A core part of our model is the idea that power can be exercised in at least three discursive levels or 'layers.' The first layer deals with actors and their discursive strategies, the second layer concerns the genres that enable and constrain sensemaking, and the third layer involves the discourses and their associated ideologies that are the basis on which sensemaking is established. 


\section{Layer 1: Discursive strategies}

In CDS, discursive strategies are ways of using available discursive resources for specific purposes, such as to influence others or mobilize action (Fairclough, 2003; Wodak and Meyer, 2015). The notion of 'discursive strategy' is useful in pinpointing specific linguistic tools or devices that are used to influence the sensemaking of others in the service of power. Thus, a critical discursive perspective allows us to elucidate the overt and visible use of power by making conceptual links between the concept of sensegiving and the fine-grained analysis of discursive strategies used in the exercise of power, such as those found in the analyses by Wodak and colleagues on managerial meetings (Wodak, Kwon and Clarke, 2011; Kwon, Clarke and Wodak, 2014).

In this 'layer', power operates in more visible ways when actors seek to influence others through discursive strategies. By 'visible', we mean both that we can 'visibly' see the written words or hear the spoken words and 'visible' in terms of the power effects we can see these discursive strategies having on the sensemaking of others. These power effects can be seen in how recipients change their sense of the situation in their talk, text, or non-verbal actions. Conceptually, these more visible aspects of power connect to the first face of power in Lukes' (1974) framework, where an actor exercises influence over another actor by getting them to do something they would not have otherwise done (Dahl, 1957).

However, even at this most visible level of power, we propose that less visible aspects of power also operate. In particular, we seek to develop a new conceptual link to 'discursive ability' (Maitlis and Lawrence, 2007; Maitlis and Sonenshein, 2010) and 'discursive competence' (Rouleau and Balogun, 2011) through consideration of the 'stratification of opportunity' to engage in sensegiving. Discursive ability is defined as the ability of organisational actors "to construct and articulate persuasive accounts of the world" (Maitlis and Lawrence, 2007: 80). Maitlis and Sonenshein (2010: 572) suggest that a "strong discursive ability" can be important in 
shaping which account comes to dominate, pointing sensemaking research towards the study of rhetoric, persuasion and influence. These more visible aspects of power are manifested in the impression management techniques, issue selling efforts, and rhetorical tactics used to persuade, lead, impress or 'give sense' to others (Balogun et al., 2015; Gioia and Chittipeddi, 1991; Maitlis and Lawrence, 2007; Rouleau and Balogun, 2011; Sonenshein, 2007, 2009).

We seek to develop a more critical perspective on discursive ability by identifying the more 'hidden' power relations that shape how discursive ability is distributed in unequal ways within organisations. Discursive ability is not evenly distributed because certain actors have the kinds of linguistic capital (Bourdieu, 1991) associated with perceptions of sensegiver legitimacy and expertise - while others do not. Impressions of the talk and text produced by sensegivers are formed not only by the frames they introduce but are also marked by assumptions and expectations regarding class, gender and other markers of social stratification. For example, class has long been known to be marked by the different 'linguistic codes' (Bernstein, 1962) used by different socio-economic groups. Accent, in the form of regional accents, working class accents and non-native 'foreign' accents, also shape how we perceive multiple aspects of what people say and how likely we are to be influenced by it (Mautner, 2016: 141). Gender is also imprinted in language use due to the systematic differences in practices of (and normative expectations of) language use according to gender (Coates, 2015), shaping the sense that is made of the talk and text produced by the sensegiver.

The unequal distribution of 'discursive ability' means that those outside of the dominant organisational elite can struggle to have their discourse recognized and accepted. As a result, their 'sense' can be systematically excluded from the organisational sensemaking process based on expectations about legitimate ways of talking or writing. Thus, we propose that advancing the critical understanding of power in sensegiving requires us to identify how 'discursive ability' is 
unevenly distributed and how this can serve to reinforce structures of dominance in organisations. We can call this phenomenon the 'stratification of discursive ability'.

\section{Layer 2: Genres}

Genres are recurrent patterns of types of speech or writing found within distinct social spheres. Fairclough (2010: 96) defines genre as the "use of language associated with a particular social activity". A genre is therefore a socially recognized and accepted set of conventions, rules and patterns of communicative interaction, which are typically enacted by social actors in habitual and taken for granted ways. Genres can incorporate a multitude of elements, including the style of language used (e.g., formal vs. informal language), the lexicon used (e.g., technical vs. colloquial), the way sentences are structured (e.g., poetry vs. prose), the way a text conforms to expectations about story development (e.g., the genre of a comedy vs. a romance) and the way turns at talk are allocated (e.g., who asks questions and who answers them). Organisations and institutions have distinct collections or 'repertoires' of genres, which may also change over time. In fact, as Fairclough (2003: 66) points out, genres differ in their degree of stabilization and even relatively fixed and ritualized genres can sometimes undergo rapid flux and transformation. Importantly for our purposes, genres can serve to disempower and disadvantage some actors engaged in interaction with organisations and institutions (Fairclough, 1994). Fairclough (2010: 182) describes genres as "devices for framing" because they work to control who gets to contribute to the discourse used in social settings and how they are allowed to contribute.

We propose that the concept of genre adds to the recent advances in the understanding of organisational sensemaking as an "un-noticed" (Holt and Cornelissen, 2013: 3), "habitual" (Sandberg and Tsoukas, 2014: 18) and "taken-for-granted" (Schildt et al., 2020: 249) process. These approaches share the assumption that sensemaking does not only occur when sense is rendered difficult or problematic during particular 'episodes' where organisational actors 
experience equivocality and struggle to make sense of what is happening. In this view, sensemaking also occurs when organisational actors are engaging in "routinized sensemaking" (Schildt et al., 2020: 251), where no active effort to create sense appears to be taking place because actors can rely on established frames. We develop this by proposing that genres reproduce the way of structuring a text or conversation in ways that are typically unnoticed and taken for granted by those involved.

As Weick (2003: 186) points out, sensemaking is a "collective, social phenomena between people" and is not as an "isolated individual phenomena inside a single head". As a result, the question of how people interact socially is paramount. Hence, genre matters. More specifically, we propose that genres shape power relations in sensemaking in two distinct ways. Firstly, genres enact power through their degrees of 'accessibility', that is, who is able to access and understand the mode of writing or talking used in the genre. Formal modes of speaking or writing and the use of technical or professional terminology render certain social groups excluded from, and therefore unable to exercise influence in, organisational sensemaking processes. Secondly, genres also enact power by shaping the nature of the participation, including both who can contribute to the text or conversation and how they are legitimately permitted to contribute. Those seeking to contribute to collective sensemaking can find their contributions limited or excluded in genres that restrict input to pre-defined types. For example, in genres involving question-and-answer genre sequences, actors can find themselves dominated by the definition of the situation (or 'frame') built into the questions and unable to articulate their own sense of the situation (see Molotch \& Boden, 1985; Thornborrow; 2002; Fairclough, 2010: 31-32). Importantly, both elements can operate in a 'hidden' manner insofar as those conforming to an established genre are typically unaware of how power is being exercised through its use.

\section{Layer 3: Discourses}


Digging even deeper into power in sensemaking requires us to ask the question: where does the discourse used in sensemaking come from? All instances of text and talk production used in the sensemaking process are founded on existing discourses. Here, 'discourses' are understood as "more or less standardised ways of constituting/reasoning about certain types of phenomena" (Alvesson and Karreman, 2011: 1126). Discourses are 'sedimented' over time as societies or social groups share and solidify their ways of making sense through language. While not every member of a society or social group will have identical 'copies' of the 'mental models' provided by the discourse (van Dijk, 1998) ${ }^{2}$, a more or less accepted and shared way of 'making collective sense' forms as the discourse is established in the social group or organisation. Van Dijk (1998: 78) uses the terms "normalization and unification" (van Dijk, 1998: 78) to describe situations when certain ways of talking and thinking become established as the 'norm' for the group and the group begins to 'unify' around these shared mental models (van Dijk, 1998: 78).

Discourses as systems of thought constitute the background for all sensemaking acts by structuring both what forms of reasoning should be used to make sense of cues and what is 'conceivable' to make sense of. According to Phillips, Lawrence and Hardy (2004: 636), discourse "makes sense of the world for its inhabitants, giving it meanings that generate particular experiences and practices". Power enters this process through the way that discourses 'rule in' and 'rule out' certain ways of making sense. As such, discourses serve to construct the 'conditions of possibility' for sensemaking, a term associated with the work of Foucault (1970) and used to refer to the social conditions necessary for a particular idea or form of knowledge to be possible. ${ }^{3}$ In organisational sensemaking situations, we propose that available discourses 'condition' actors by shaping what is possible for them to 'sense'. Thus, we propose discourses have constitutive power effects insofar as certain cues in our perceptual environment only come to be 'bracketed

\footnotetext{
2 The term 'mental models' is also used by Weick (1995: 37) and Weick, Sutcliffe and Obstfeld (2005).

${ }^{3}$ Foucault's work has been a source of inspiration for Fairclough and has been integrated into Critical Discourse Studies, amongst others, through Fairclough's work (1989; 2010: 51).
} 
in' to our attention, and ultimately made meaningful, if the available discourses enable us to single them out from the "undifferentiated flux of raw experience" (Chia, 2000: 517).

Importantly for our purposes, by 'ruling in' and 'ruling out' certain ways of making sense, dominant discourses serve ideological purposes by shaping what is seen as natural, inevitable or right (Fairclough, 2010; van Dijk, 1998). Ideology is here defined as "political or social systems of ideas, values or prescriptions of groups or other collectivities" which serve the function of "organizing or legitimating the actions of the group" (van Dijk, 1998: 3). Fairclough (2010: 8) cites a simpler definition of ideology by Thompson (1984), namely: "meaning in the service of power". While discourses are not the only means through which ideologies are (re)produced, given the role of other semiotic modes and social rituals in ideological reproduction, we follow van Dijk (1998: 6) in viewing discourses as the central means through which ideologies are socially shared, reproduced and challenged.

We now finally turn to consider the ideological 'obfuscation' of power developed in CDS (van Dijk, 1998, 2018) - and come back to the notions of sensegiving and discursive strategies. The concept of sensegiving emphasises the more strategic, agentic, and visible aspects of power and influence through its focus on the deliberate attempts of actors to influence the sensemaking of others (Gioia and Chittipeddi, 1991; Maitlis and Lawrence, 2007). However, this conception of sensegiving does not capture the way in which power operates not only through the effect of the discourse on the sensemaking of recipients, but also through the way that power is 'obscured' or 'hidden' in the discourse. We propose that discourses reproduce ideologies by working to "conceal, hide or otherwise obfuscate" (van Dijk, 1998: 138) the mechanisms of oppression in ways that are typically opaque to those using them to make sense.

A central tenet of CDS is that power can operate in 'opaque' ways and this opacity is central to the way that relations of domination are reproduced (Fairclough, 1993; Wodak, 2015). Thus, discourse has effects on the sensemaking of actors by making them accept a social system that 
serves the interests of dominant social groups but in ways that are not always apparent to them. Here, CDS connects to the third face of power in Lukes's (1974) framework by showing how the use of particular discursive strategies serves to legitimate and reproduce the domination of certain groups within a social arrangement.

Power relations can be obscured in discourse through the use of particular discursive strategies to downplay or conceal unequal power relations. This includes not only the choice of words but also the choice of grammatical structure. For example, use of passive voice can obscure the 'agent' performing the action and therefore conceal those responsible for the action or situation (Mautner, 2016: 77-82). In organisational sensemaking contexts, then, a CDS perspective draws our attention to how talk and text can be constructed to 'hide' or render 'opaque' the power relations underlying events. While recipients can sometimes 'see through' discourses that seek to obscure power relations, for example when they produce cynical readings of corporate texts that attempt to obscure managerialist agendas (Llewellyn and Harrison, 2006) or recognize business 'bullshit' as a 'con trick' (Spicer, 2017), the ideologies underpinning a discourse typically operate 'under the radar'. Structures of domination can thereby maintain the consent of those dominated, and sometimes even gain their active and willing support, by obscuring who is controlling whom and for what purposes. The analysis of discourses used to obfuscate power relations therefore enables us to elucidate the 'systemic power' in sensemaking, namely how the "active consent of dominated individuals and groups" (Schildt et al., 2020: 244) is achieved.

\section{Outcomes of Discursive Sensemaking}

The use of discursive practices in sensemaking leads to the generation of meanings, which in organisational contexts are used by actors to find collective answers to the questions "what is going on here?" and "what should we do?" By drawing on and extending the CDS perspective, 
we propose that this 'outcome' - the resulting 'sense' of the situation - can take one of three forms: 'common sense', 'new sense', or 'non-sense'.

\section{Outcome 1: 'Common sense'}

We propose that the CDS perspective can be particularly useful for understanding ideological reproduction and transformation and suggest using the concept 'common sense' for this outcome. If we accept Fairclough's (2001: 76) argument that "naturalization is the royal road to common sense", then we propose that the discursive construction of 'common sense' helps us to understand the reproduction of 'systemic' forms of power in sensemaking. Discourses serve to reproduce unequal power relations when members of dominated or oppressed groups view the 'mental models' (van Dijk, 1998: 78) or 'ways of thinking' carried in the dominant discourse as either "a reflection of their own goals, desires and interests" or as "a representation of a natural or otherwise legitimate social order" (van Dijk, 1998: 102).

As a result, the ideologies carried in these discourses "turn into beliefs that are taken for granted or simply common sense" (van Dijk, 1998: 102, emphasis added). Dominated groups using this 'common sense' are then unable, or unwilling, to conceive of alternative ways of making sense of themselves or their situation. To use Weick's terms, the reproduction of common sense creates a "trained incapacity to see the world differently" (Weick, 2001: 20). Power operates in a 'hidden' way because the discourse has a 'taken for granted' quality, meaning people remain unaware of how their sensemaking is being influenced by the discourses they use and how particular social groups are systemically advantaged or disadvantaged by these discourses.

\section{Outcome 2: 'New sense'}

Whereas the concept of 'common sense' captures the periods of stability where established power relations are reproduced, the concept of 'new sense' is proposed to capture the moments 
where power relations are challenged and social change occurs. This relates to classic sensemaking studies where a new sense of a situation is established (Weick, 1995, 2000). In fact, many of Weick's classic pieces of work are about the need to think differently or to create new sense during “cosmology” episodes (Weick, 1993; 1995, 2010).

Importantly, though, we propose that 'new sense' can emerge not only from consensual attempts by collectives to grapple with ambiguity but also from power-infused discursive contests. As Mikkelsen, Gray and Petersen (2000) point out, the typical focus of sensemaking studies on consensual processes of generating order and meaning to enable coordinated action eschews the "sometimes-conflictual nature of meaning in organizing processes" (p. 1356, emphasis added). In discursive conflicts, ways of making sense generated by dominant discourses can be subject to resistance in the "hegemonic struggle" (Fairclough, 2010: 126) created by competing discourses. Here the 'direction' of power is reversed: a particular 'sense' that had previously become taken for granted 'common sense' is questioned, resisted, and eventually replaced with a 'new sense'.

To challenge what has become 'common sense', there is not only a need for alternative discourses that 'carry' different ideological assumptions but also a more fundamental need to 'denaturalize' (Fairclough, 1985) the sense currently viewed as 'natural', 'obvious' and 'right'. Rather than an individual-level cognitive process, we propose that denaturalization should be viewed as a social process of drawing on or creating a counter-discourse. Counter-discourses can be created from novel senses that emerge when people seek new linguistic expressions for their experiences or emotions (such as with the phrases 'Me Too' or 'Black Lives Matter'), from the importation of discourses from one domain into another domain, or from novel combinations of existing discourses. As counter-discourses are distributed and shared, they can be amplified and extended until they reach a position of being able to challenge the dominant 'common sense'. Importantly, this process of sharing, amplifying, and extending counter-discourses can take place with various degrees of formal organisation and coordination. This captures both the 
emancipatory process through which counter-discourses emerge from the spontaneous sharing of talk and text that de-naturalizes dominant discourses (such as activism that emerges from social media interactions) and the more formal attempts to coordinate counter-discourses (such as social change coordinated by social movement organisations).

\section{Outcome 3: 'Non-sense'}

Going further, we also suggest that analytic attention should be paid to the power-infused process whereby sensemaking that deviates from the prevailing 'common sense' worldview is dismissed as 'non-sense'. In our view, non-sense needs to be conceptualized not only as a state of 'senselessness' where actors lack meaning or suddenly lose meaning (Weick, 1985; 1993) or as meaningless and vacuous 'bullshit' (Christensen et al., 2019; McCarthy, et al., 2020; Spicer, 2017) that pervades organisational life. We propose that non-sense also involves a power-laden process through which alternative ways of making sense that deviate from 'common sense' are delegitimated and dismissed or, at its extreme, are simply inconceivable. We propose that two distinct power-laden sensemaking processes operate here.

The first process occurs when 'new sense' emerges that threatens the prevailing power structures and is dismissed as 'non-sense' by those seeking to maintain the dominant discourses that maintain the status quo. In the aftermath of the 2008 Financial Crisis, for example, think tanks, academics, corporations, political parties, and the media coalesced so tightly around a single discourse of austerity (Berry, 2016, 2019; Kelsey et al., 2016; Borriello, 2017; Pautz, 2018) that any talk of alternatives to austerity (such as allowing banks to fail or raising taxes) were dismissed as 'non-sense'. At the organisational level, actors can fail to 'notice' changes in the environment as a result of the domination of a particular discourse. For example, Glynn and Watkiss (2020) discuss using Fligstein et al.'s (2017) analysis of why the Federal Reserve's failed 
to recognize the early stages of the 2008 Financial Crisis due to the total dominance of 'frames' provided by macroeconomic theory.

A range of discursive and non-discursive strategies can be used to dismiss an alternative sense as 'non-sense'. Texts (or their authors) can be discredited as 'wishful thinking' or 'dangerous ideology', or the texts themselves can be removed from circulation, to marginalize or sideline alternative ways of thinking. The exception to this occurs when, as Heracleous (2006) points out, those developing alternative discourses articulate themselves using the argumentative structures, value-systems, logics and 'modes of reasoning' present in the dominant discourse used by those in power, with a view to gaining legitimacy before later moving to dismantle the dominant group and their discourse.

The second process is even more insidious because it occurs when no alternative sense is even conceivable because of the hegemonic dominance of the common sense discourse. A discourse can be said to have hegemonic dominance when it has widespread acceptance and the domination is exercised on the basis of consent rather than coercion. Here, we build on the argument about ideology developed by Fairclough (1989) and van Dijk (1998) that dominant discourses play in taking some ways of thinking 'off the agenda'. Alternative ways of thinking become inconceivable when a discourse has reached a fully hegemonic status in a social group, organisation or society.

Dominant discourses achieve hegemonic status through a process known as "naturalization" (Fairclough, 2001: 76). Naturalization occurs when discourses that serve the interests of a particular social group are viewed as neutral or natural - or sometimes even beneficial - by those being dominated. The dominant discourse becomes so taken for granted that it no longer appears to people as a politically invested perspective but rather as the 'obvious', 'proper' or 'correct' way of making sense. The sensemaker views "ideological representations" (Fairclough, 2010: 34) 
as nothing of the sort. Instead, these representations are "taken as commonsensically given" (Fairclough, 2010: 34) by members of the collective.

Making sense using a hegemonic discourse feels 'natural' to those involved, meaning no alternative is likely to be conceived, let alone articulated as a discourse. If "it is the job of the sensemaker to convert a world of experience into an intelligible world" (Weick, 2001: 9), then we propose that hegemonic discourses also operate to render certain things "unintelligible" (Weick, Sutcliffe and Obstfeld, 2005) to the sensemaker. Power is at its most 'hidden' in this process because the hegemonic discourses render people 'blinkered' or 'blind' to the way their sensemaking is being dominated. This outcome connects us back to the ongoing cycle of sensemaking, namely when the sense made of the next event or issue is shaped by the 'blind spots' created by the hegemonic discourse. We propose that the alternative senses that are dismissed or are inconceivable lead organisational actors to fail to notice and attend to cues in their environment because they do not have the language through which they can make sense of them.

Here, we draw conceptual links between the concepts of 'bracketing' used in sensemaking research (Weick, Sutcliffe and Obstfeld, 2005) by pointing to the role of hegemonic discourses in generating the 'blind spots' that make actors unable, or unwilling, to notice and attend to cues in their environment. Weick (2001: 460) proposed that "to make sense it to focus on a limited set of cues" (our emphasis). Later, Weick (2020) proposed that sensemaking "brackets and stabilizes some segment of ongoing flux" (p. 1422, our emphasis) and "carves brackets around some portion of the flux" (p. 1426, our emphasis). We develop these ideas further by proposing that hegemonic discourses lead us to 'bracket in' only those cues that are meaningful and intelligible within the language and associated form of reasoning that these discourses provide: what van Dijk (1998: 78) refers to as the 'mental models' provided by a discourse. Everything else is 'bracketed out' and the unextracted cues remain either unnoticed (in the case of the alternative senses that are inconceivable) or noticed but disregarded (in the case of the alternative senses that are dismissed). 
While the cues are received by the senses - for example as something we hear, see, touch or smell - without the language with which to make sense of them, they are not integrated into the meaning-making process. While sensemaking scholars normally start with analysis of those cues which "catches people's attention" as a result of "bracketing portions of experience for closer inspection and further action" (Tsoukas et al., 2020), the concept of non-sense captures those things 'bracketed out' of attention. Only by finding or building a language with which to make sense of these unnoticed or disregarded cues, we propose, can they be 'bracketed in' to the sensemaking process.

\section{DISCUSSION}

Our analysis makes four main contributions. First and foremost, we illuminate the discursive underpinnings of power in sensemaking, thus adding a missing piece to sensemaking research. Second, our discursive analysis also contributes to sensemaking research by elucidating the role of language in sensemaking more generally. Third, our framework gives rise to methodological ideas that can advance our understanding of discursive power in sensemaking. Fourth and finally, by offering ways to make conceptual and methodological connections between CDS and sensemaking, our analysis also adds to critical organisational discourse studies more generally.

\section{Elucidating the Discursive Underpinnings of Power in Sensemaking}

The purpose of this paper has been to answer the calls to place power at the center of sensemaking research (Brown, Colville and Pye, 2014; Maitlis and Christianson, 2014; Maitlis and Sonenshein, 2010; Shildt et al, 2020; Weick et al, 2005). Rather than treating power as merely a matter of politicking or as an outcome of efforts to influence the sensemaking of others, we have argued for a 'deeper' view where power operates in less visible and progressively more hidden 
ways through the discursive practices used in sensemaking. By so doing, our framework can be seen as offering a sorely needed missing link between language and power in sensemaking research.

Bringing power into sensemaking through a critical discursive perspective allows us to view the intersubjective process of sensemaking as a site of power struggle - thus adding to how sensemaking is usually seen or defined (see e.g., the definition by Maitlis and Christianson, 2014). In our view, the key to this struggle can be found in discursive practices, and we maintain that without unravelling the role of these discursive practices, our understanding of power easily remains superficial - as if power, language and sensemaking would be separate things. As our model highlights, there are different aspects of this power struggle - discursive strategies, genres, and discourses - each of which warrants attention in sensemaking research.

In the first instance, it is a question of struggle between actors who use discursive strategies to influence others and frame issues. Even here, though, where power is in its most 'manifest' or 'overt' form, more latent and systemic forms of power operate through the unequal distribution of discursive ability. The struggle over meaning is also fundamentally linked with the prevailing genres through which certain groups gain or maintain control over others. In addition, it is grounded in the available discourses that offer specific vocabularies, frames or 'mental models' for sensemaking - with ideological assumptions being carried with them in ways that are typically obscured. We maintain that digging deeper through such analysis helps to move beyond the idea that sense as intersubjective meaning-making is a predominantly neutral and consensual process, unaffected by the power relationships and social structures of the setting. Unravelling these discursive underpinnings helps us to understand also the 'latent' or 'hidden' aspects of power that the conventional focus on 'manifest' power ignores (Willmott, 2013). In particular, our analysis highlights the role of genres and discourses in 'pre-structuring' sense. These aspects are, we 
propose, a key component of 'immanent' or 'habitual' sensemaking, thus adding to recent work in this area (Holt and Cornelissen, 2014; Introna, 2019; Sandberg and Tsoukas, 2015).

We also advance understanding of the power-infused conditions of possibility of sensemaking. Although Weick does not use the term 'conditions of possibility', his two seminal books (Weick, 1995, 2001) do include in-depth reflection about how certain senses may or may not emerge, and why. Our analysis helps to pin down some of the key conditions through which some senses readily emerge and proliferate while others do not. By identifying the hegemonic discourses that pre-structure sensemaking, we can begin to see how some senses seem 'obvious' and 'right' while other sensemaking possibilities are precluded when alternative senses are dismissed or are simply inconceivable. Importantly, our analysis also illuminates how the outcomes of sensemaking are power-laden. We have suggested that sensemaking vocabulary should be supplemented with the terms of 'common sense', 'new sense' and 'non-sense' to understand why specific ways of making sense seem to 'click', 'take off' or 'resonate' and others do not.

Our framework is deliberately inspired by Weick's point about the 'retention' (Weick, 2001: 305) of frames for use in future sensemaking situations, represented by the feedback loop at the bottom of Figure 1. The sense that actors make in the 'here-and-now' needs to be studied both 'backwards' and 'forwards', by which we mean how the sense generated here-and-now carries traces of past sensemaking situations and also has implications for future sensemaking situations. Accordingly, the dynamics of stability and change in power relations require a longitudinal focus. Power structured are reproduced when common sense is reproduced over time and any 'new sense' is dismissed or disregarded as 'non-sense'. Change in power structures occurs when new ways of making sense are created and begin to gain acceptance, triggered by shifts in discursive strategies, genres or discourses. 


\section{Understanding the Role of Language in Sensemaking}

Our analysis also advances theoretical understanding of the linguistic underpinnings of sensemaking more generally. Early on, Weick recognized the key role of language in sensemaking, pointing out that "words figure in every step" (Weick, 1995: 106) of the sensemaking process and repeating the well-known and much-cited phrase "how can I know what I think until I see what I say?" (Weick, 1979: 5; 1995: 12; 2001: 95) Notwithstanding, in their review and agenda for the field, Maitlis and Christianson (2014) have called for more in-depth understanding of the discursive aspects of sensemaking. Our framework highlights the constitutive role of discursive practices in sensemaking and both their manifest and latent power implications. It specifically sheds light on where the language used in sensemaking "comes from" in the form of prevailing discourses as systems of thought. This extends the scale and scope of sensemaking analysis beyond the 'here and now' analysis of group interaction to the kinds of historically and culturally contingent systems of knowledge that provide the discourses that constitute the 'conditions of possibility' of sensemaking. In addition to recognising the key role of language in acts of sensemaking, our analysis offers conceptual tools to elucidate the powerladen 'infrastructure' of the discursive construction of reality that has remained undertheorized in existing sensemaking scholarship.

By so doing, our analysis adds to the trajectory of work that emphasises the role of the social processes and practices in sensemaking, building further on a movement from the cognitivist tradition toward new conceptualizations of sensemaking (Brown et al, 2014; Helms Mills et al, 2010; Holt and Cornelissen, 2014; Sandberg and Tsoukas, 2015; Schildt et al., 2020). Our contribution to this movement lies in elucidating how the more 'latent' and 'hidden' aspects of discursive practices are implicated in sensemaking. Our critical discursive perspective, which may at first appear alien to conventional sensemaking scholarship, has special potential in advancing theory-building in sensemaking due to its resonance with the recent calls for focus on more 
'latent' or 'immanent' aspects of sensemaking (Holt and Cornelissen, 2014; Introna, 2019; Sandberg and Tsoukas, 2015).

\section{Methodological Implications}

There are several methodological implications for those seeking to operationalize the framework developed here in future research to address the future research questions listed in the final column of Tables 1 and 2. The common methodological tools used by qualitative sensemaking scholars - observational fieldwork, recordings of interaction and interviews - can be enhanced with methods that enable us to capture and illuminate the power dynamics in our framework. For example, scholars wanting to study of how discursive practices shape the 'bracketing in' and 'bracketing out' of cues could use video recording technology to slow down and analyse the verbal and non-verbal interactions that led to certain cues being noticed and pieced together using the 'frames' provided by the discursive practices used. These kinds of multimodal methods can also be used in the study of crises, accidents, and disasters to pinpoint the discursive strategies, genres and discourses that have contributed to certain cues being 'missed' or cues being 'pieced together' in ways that precipitated or mitigated disaster.

The study of 'common sense' from our framework has two main methodological implications. The first implication is regarding the choice of what situations to study. Sensemaking scholars have typically studied moments where making sense is problematic in some way. This could be because the actors struggle to make sense of what is happening during unusual situations such as a crisis or disaster, or because actors fail to reach a shared understanding of what is happening to enable coordinated action. However, this choice of focus sidesteps the ordinary, mundane aspects of routine organisational life where sense is made readily and apparently effortlessly because it draws on what is existing shared 'common sense'. As Rawls (2008: 724) points out: "Collaborative sensemaking is not just something that happens when 
things break down; it is happening in every meaningful moment." Scholars can therefore make a deliberate choice in future research to focus on understanding these apparently 'normal' sensemaking situations to unpack the discursive strategies, genres and discourses that enable them to appear mundane and pass unnoticed. Just as Weick's work makes the 'exotic' appear 'mundane' by showing how disasters unfold through the sensemaking that creates disorganisation, scholars can also use our framework to make the 'mundane' appear 'exotic' by analysing situations where 'common sense' is reproduced in ways that enable organisation or produce disorganisation.

The second implication lies in the methodological tools available to study common sense. Scholars could make use of developments in the study of interaction in ethnomethodology and its related off-shoot branches of conversation analysis and membership categorisation analysis (Heritage, 1984; Rawls, 2008). Future studies could hone in specifically on how actors use their common sense social knowledge in ongoing interaction, creating important links to our conceptualization of 'common sense' as an input into and outcome of power relations. Ethnomethodological approaches also include analysis of multimodal interaction, for example through the study of how turns at talk, social categories, gestures, and bodily movement enable the production of the 'sense' that enables order and organisation. Such analysis enables us to capture the ideological implications of what (currently) passes as 'common sense'.

Scholars focusing on 'zooming in' on the unfolding of interaction at the micro-level, for example by analysing recordings of fieldwork observations of a specific situation where sense is being made of an issue or event, can also 'zoom out' and 'trace back' to capture the discourses being used in the specific situation being analysed. By 'zooming out' we mean using supplementary methods, such as analysis of organisational documents or media reports, to explore where the discourses and genres being used in the situation come from in the broader organisational field or society. The researcher can ask: where, when, how and with what effects 
is this discourse being produced, circulated and used? By 'looking back', we refer specifically to adopting a historical mindset and tracing back in time where and when the discourse-in-use emerged. This also has methodological implications, namely the adoption of historical methods such as archival analysis to enrich a focus on a contemporary event. Furthermore, rather than a focus on studying sensemaking during 'one off' events, a longitudinal analysis would enable the researcher to trace how certain ways of making sense are accepted and retained over time, while others are disregarded and dismissed.

\section{Advancing Critical Discursive Studies in the Organisational Context}

Finally, it is useful to consider how this analysis links with the stream of research using CDS and related perspectives in organisation studies (Chouliaraki and Fairclough, 2010; Fairclough, 2005; Leitch and Palmer, 2010). Critical discursive perspectives have been used in a variety of ways and have advanced our understanding of a number of theoretical issues and empirical phenomena (Phillips et al, 2004; Phillips et al., 2008; Vaara et al, 2005; Vaara and Tienari, 2008; Kwon et al., 2020). Interestingly, this has sometimes meant using sensemaking terminology without paying attention to the concepts used or the linkages to sensemaking 'theory'.

In all, our framework offers a theoretically grounded set of concepts that can be useful in future studies adopting a critical discursive lens in the organisational context. This is especially the case with the framework that elaborates on how discursive strategies, genres and discourses lie at the heart of the sensemaking process. Moreover, and perhaps most importantly, we also suggest that common sense, new sense and non-sense could be used as terms that help to understand the organisational and societal implications of the discursive construction of reality. We believe that it is through such theoretical work that we can advance the critical organisational 
discourse analysis and to promote a fruitful dialogue between scholars in different traditions interested in the organisational phenomena.

\section{CONCLUSION}

Studying power in sensemaking from a discursive lens makes a lot of sense if we want to advance sensemaking not as a separate stream of research but as an increasingly important body of work that has the capacity to move management and organisation theory forward. The alternative is that research on sensemaking and research on power and discourse would follow their own independent trajectories, losing the potential for theory-building at the intersections of these streams of research.

We hope that our framework can inspire future work on discursive sensemaking, and the research questions summarized in Tables 1 and 2 offer fruitful avenues for future research. This can involve analysis of situations ranging from 'cosmology' episodes (Cornelissen et al, 2014; Weick, 1993), where actors lack the means to make sense, to 'mundane' situations where the senses available are taken-for-granted and not questioned at all (Holt and Cornelissen, 2014; Sandberg and Tsoukas, 2015), driven as they are by 'common sense'. Analysis of how power operates therefore needs to combine the study of visible struggles over power between actors with study of how power works in more 'hidden' ways through the less visible struggles over meaningmaking that are shaped by discursive practices.

While we have focused on three types of sense as outcomes of power-laden discursive sensemaking - common sense, new sense and non-sense - future research could elaborate on these and other forms as well as their relationships. For instance, 'bullshit' seems to be a particularly intriguing phenomenon because it is simultaneously regarded as 'non-sense' but nonetheless typically passes unchallenged and unnoticed in the same way as 'common sense' does (Christensen et al., 2019; McCarthy, et al., 2020; Spicer, 2017). Uncovering such complex, 
ambiguous and at times paradoxical aspects of discursive sensemaking is a major challenge for future research.

Our analysis can also be linked with theoretical ideas in other areas such as framing in social movements. The concept of 'resonance' first used in the literature on framing (Snow and Benford, 1988) and developed recently by Giorgi (2017) is likely to be an important avenue for further development of our work here. Ideas that 'fall in line' with dominant discourses could be more likely to 'resonate' because they confirm common-sense assumptions and therefore intuitively 'feel right'. Common-sense is further reinforced in organisations and in society when the only ideas that get 'taken up' are those which follow common-sense, further reinforcing the notion that this common-sense must be 'right' and should not be questioned. Another related link that could be made in future work is with the concept of 'discursive opportunities' (Koopmans and Olzak, 2004). For instance, future studies could examine how certain ideas get noticed and 'taken up' by wider audiences based on the discursive 'structures of opportunity' as outlined in our framework.

Overall, like Tsoukas et al. (2020), we see special opportunities in studying forms of discursive sensemaking in today's technologically mediated modes of communication and mediatized society, which has brought about new channels, platforms, and practices for collective sensemaking. Such analysis can help to better understand, for instance, the role of sociomateriality and multimodality in new forms and modes of organisational discourse. 


\section{REFERENCES}

Abolafia, M. Y. (2010). Narrative construction as sensemaking: How a central bank thinks. Organisation Studies, 31, 349-367.

Alvesson, M., and Karreman, D. (2000). Varieties of discourse: On the study of organisations through discourse analysis. Human Relations, 53(9), 1125-1149.

Alvesson, M., and Kärreman, D. (2011). Decolonializing discourse: Critical reflections on organisational discourse analysis. Human Relations, 64(9), 1121-1146.

Aromaa, E., Eriksson, P., Helms Mills, J., Hiltunen E., Lammassaari, P. and Mills, A.J. (2018). Critical sensemaking: Challenges and promises. Qualitative Research in Organisations and Management: An International Journal, 14(3): 356-376.

Balogun, J., Bartunek, J. M., Do, B. (2015). Senior managers' sensemaking and responses to strategic change. Organization Science, 26, 960-979.

Balogun, J., Jacobs, C., Jarzabkowski, P., Mantere, S. and Vaara, E, (2014). Placing strategy discourse in context: Sociomateriality, sensemaking, and power. Journal of Management Studies, 51, 175-201.

Balogun J., Jarzabkowski, P. and Vaara, E. (2011). Selling, resistance and reconciliation: A critical discursive approach to subsidiary role evolution in MNEs. Journal of International Business Studies, 42, 765-786.

Balogun, J., Johnson, G. (2004). Organisational restructuring and middle manager sensemaking. Academy of Management Journal, 47, 523-549.

Bernstein, B. (1962). Social class, linguistic codes and grammatical elements. Language and Speech, 5, 221-240.

Berry, M. (2016). No alternative to austerity: How BBC broadcast news reported the deficit debate. Media, Culture and Society 38, 844-863.

Berry, M. (2019). The media, the public and the great financial crisis. Basingstoke: Palgrave Macmillan.

Borriello, A. (2017). 'There is no alternative': How Italian and Spanish leaders' discourse obscured the political nature of austerity. Discourse and Society, 28, 241-261.

Boudes, T., Laroche, H. (2009). Taking off the heat: Narrative sensemaking in post-crisis inquiry reports. Organisation Studies, 30, 377-396.

Bourdieu, P. (1991). Language and Symbolic Power. Cambridge: Polity Press.

Brown, A. D. (2000). Making sense of inquiry sensemaking. Journal of Management Studies, 37, 45-75.

Brown A., D. (2004). Authoritative sensemaking in a public inquiry report. Organization Studies, 25, $95-112$.

Brown, A. D. (2005). Making sense of the collapse of Barings Bank. Human Relations, 58, 15791604.

Brown, A. D., Colville, I. and Pye, A. (2014). Making sense of sensemaking in Organisation Studies. Organisation Studies, 36, 265-277.

Brown, A. D. and Humphreys, M. (2003). Epic and tragic tales. Journal of Applied Behavioral Science, 39, 121-144.

Brown, A. D. and Jones, M (2000). Honourable members and dishonourable deeds: Sensemaking, impression management and legitimation in the 'Arms to Iraq Affair'. Human Relations, 53, 
655-689.

Budd, K., Kelsey, D., Mueller, F., and Whittle, A. (2019). Metaphor, morality and legitimacy: A critical discourse studies of the media framing of the payday loan industry. Organization, 26, $802-829$.

Chia, R. (2000). Discourse analysis as organisational analysis. Organization, 7, 513-518.

Chouliaraki, L., \& Fairclough, N. (2010). Critical discourse studies in organisational studies: Towards an integrationist methodology. Journal of Management Studies, 47(6): 1213-1218.

Christensen, L. T., Kärreman, D., and Rasche, A. (2019). Bullshit and Organisation Studies. Organisation Studies, 40, 1587-1600.

Clark, E. and Geppert, M. (2011). Subsidiary integration as identity construction and institution building: A political sensemaking approach. Journal of Management Studies, 48, 395-416.

Clegg, S. R. (1989). Radical revisions: Power, discipline and organisations. Organization Studies, 10, 97-115.

Clegg, S. R., Courpasson, D. and Phillips, N. (2006). Power and Organisations. London: Sage.

Clegg, S., Flyvbjerg, B. and Haugaard, M. (2014). Reflections on phronetic social science: A dialogue between Stewart Clegg, Bent Flyvbjerg and Mark Haugaard. Journal of Political Power, 7, 275-306.

Coates, J. (2015). Women, men and language: A sociolinguistic account of gender differences in language. London: Routledge.

Cornelissen, J. P., Mantere, S. and Vaara, E. (2014). The contraction of meaning: The combined effect of communication, emotions, and materiality on sensemaking in the Stockwell Shooting. Journal of Management Studies, 51, 699-736.

Dahl, R. (1957). The concept of power. Behavioral Science, 2, 201-215.

Dutton, J. E. and Ashford, S. J. (1993). Selling issues to top management. Academy of Management Review, 18, 397-428.

Dutton, J. E., Ashford, S. J., O’Neill, R. M. and Lawrence, K. A. (2001). Moves that matter: Issue selling and organisational change. Academy of Management Journal, 44, 716-736.

Dutton, J. E. and Dukerich, J. M. (1991). Keeping an eye on the mirror: Image and identity in organisational adaptation. Academy of Management Journal, 34, 517-554.

Dutton, J. E. and Duncan, R. B. (1987). The creation of momentum for change through the process of strategic issue diagnosis. Strategic Management Journal, 8, 279-295.

Dörrenbächer, C. and Geppert, M. (2006). Micro-politics and conflicts in multinational corporations: Current debates, re-framing, and contributions of this special issue. Journal of International Management, 12, 251-265.

Dörrenbächer, C. and Geppert, M. (2011). Politics and Power in the Multinational Corporation: The role of institutions, interests and identities. Cambridge: Cambridge University Press.

Fairclough, N. (1985). Critical and descriptive goals in discourse analysis. Journal of Pragmatics, 9, 739-763.

Fairclough, N. (1989/2001). Language and Power. London: Longman.

Fairclough, N. (1995). Media Discourse. London: Edward Arnold.

Fairclough, N. (1994). 'Conversationalization of public discourse and the authority of the consumer'. In Keat, R., Whiteley, N., and Abercrombie, N. (Eds.). (1994). The authority of the consumer. London: Routledge, pp. 245-259.

Fairclough, N. (2003). Analysing Discourse. London: Routledge. 
Fairclough, N. (2005). Peripheral vision: Discourse analysis in organisation studies: The case for critical realism. Organization Studies, 26(6): 915-939.

Fairclough, N. (2010). Critical discourse studies. 2nd edition. London: Routledge.

Fairclough, N. \& Wodak, R. 1997. Fairclough, N., \& Wodak, R. (1997). Critical discourse analysis. In T. van Dijk (Ed.), Discourse Studies: A Multidisciplinary Introduction (Vol. 2), pp. 258284. London: Sage.

Fiss, P. C. and Hirsch, P. M. (2005). The discourse of globalization: Framing and sensemaking of an emerging concept. American Sociological Review, 70, 29-52.

Fleming, P. and Spicer, A (2014). Power in management and organisation science. Academy of Management Annals, 8, 237-298.

Fligstein, N., Stuart Brundage, J. and Schultz, M. (2017). Seeing like the fed: Culture, cognition, and framing in the failure to anticipate the financial crisis of 2008. American Sociological Review, 82, 879-909.

Forchtner, B. \& Wodak, R. 2019. Critical discourse studies: A critical approach to the study of language and communication. In Forchtner, B. \& Wodak, R. 2019 (eds), The Routledge Handbook of Language and Politics. London: Routledge. Pp. 135-149.

Foucault, M. (1970). The Order of Things. London: Tavistock.

Foucault, M. (1980). Power/Knowledge: Selected Interviews and Other Writings, 1972-1977. New York: Pantheon.

Gephart, R. P. (1984). Making sense of organizationally based environmental disasters. Journal of Management, 10, 205-225.

Gephart, R. P. (1993). The textual approach: Risk and blame in disaster sensemaking. Academy of Management Journal, 36, 1465-1514.

Geppert, M., Becker-Ritterspach, F. and Mudambi, R. (2016). Politics and power in multinational companies: Integrating the international business and Organization Studies perspectives. Organisation Studies, 37, 1209-1225.

Glynn, M. A., \& Watkiss, L. (2020). Of organizing and sensemaking: From action to meaning and back again in a half-century of Weick's theorizing. Journal of Management Studies, 57, 13311354.

Gioia, D. A. and Chittipeddi, K. (1991). Sensemaking and sensegiving in strategic change initiation. Strategic Management Journal, 12, 433-448.

Giorgi, S. (2017). The mind and heart of resonance: The role of cognition and emotions in frame effectiveness. Journal of Management Studies, 54, 711-738.

Helms Mills, J. (2003). Making Sense of Organizational Change. New York: Routledge.

Helms Mills, J. (2005). Organisational change and representations of women in a North American utility company. Gender, Work and Organization, 12, 242-269.

Helms Mills, J. and Mills, A. (2000). Rules, sensemaking, formative contexts and discourse in the gendering of organisational culture. Ashkanasy, N. M., Wilderom, C. and Peterson, M., eds. Handbook of Organizational Culture and Climate. Thousand Oaks, CA: Sage, 55-70.

Helms Mills, J., Thurlow, A. and Mills, A. J. (2010). Making sense of sensemaking: the critical sensemaking approach. Qualitative Research in Organizations and Management, 5, 182-195.

Heracleous, L. (2006). A tale of three discourses: The dominant, the strategic and the marginalized. Journal of Management Studies, 43, 1059-1087.

Heritage, J. (1984). Garfinkel and Ethnomethodology. Cambridge: Polity Press. 
Holt, R. and Cornelissen, J. (2014). Sensemaking revisited. Management Learning, 45, 525-539.

Höllerer, M., Van Leeuwen, T., Jancsary, D., Meyer, R., Andersen, T, and Vaara, E. 2019. Visual and Multimodal Research in Organisation and Management Studies. Routledge: New York / London.

Huzzard, T. (2004). Communities of domination? Reconceptualising organisational learning and power. Journal of Workplace Learning, 16, 350-361.

Ibarra, H. and Andrews, S. B. (1993). Power, social influence, and sense making: Effects of network centrality and proximity on employee perceptions. Administrative Science Quarterly, 38, 277-303.

Introna, L. D. (2019). On the making of sense in sensemaking: Decentred sensemaking in the meshwork of life. Organization Studies, 40, 745-764.

Kaplan, S. (2008). Framing contests: Strategy making under uncertainty. Organization Science, 19, $729-752$.

Kelsey, D., Mueller, F., Whittle, A., and Khosravinik, M. (2016). Financial crisis and austerity: Interdisciplinary concerns in critical discourse studies. Critical Discourse Studies, 13, 1-19.

Koopmans, R., \& Olzak, S. (2004). Discursive opportunities and the evolution of right-wing violence in Germany. American Journal of Sociology, 110, 198-230.

Kress, G R. and Van Leeuwen, T. (2001). Multimodal Discourse: The Modes and Media of Contemporary Communication. London: Arnold.

Kwon, W., Clarke, I. and Wodak, R. (2014). Micro-level discursive strategies for constructing shared views around strategic issues in team meetings. Journal of Management Studies, 51, 265-290.

Kwon, W., Clarke, I., Vaara, E., Mackay, R. \& Wodak. R. 2020. Using verbal irony to move on with controversial issues. Organization Science, 31(4): 865-886.

Leitch, S., \& Palmer, I. 2010. Analysing texts in context: Current practices and new protocols for Critical discourse studies in organisation studies. Journal of Management Studies, 47(6): 11941212.

Llewellyn, N., and Harrison, A. (2006). Resisting corporate communications: Insights into folk linguistics. Human Relations, 59, 567-596.

Lukes, S. (1974). Power: A Radical View . Houndmills: Macmillan.

Maitlis, S. (2004). Taking it from the top: How CEOs influence (and fail to influence) their boards. Organisation Studies, 25, 1275-1311.

Maitlis, S. (2005). The social processes of organisational sensemaking. Academy of Management Journal, 48, 21-49.

Maitlis, S. and Christianson, M. (2014). Sensemaking in organisations: Taking stock and moving forward. Academy of Management Annals, 8, 57-125.

Maitlis, S. and Lawrence, T. B. (2007). Triggers and enablers of sensegiving in organisations. Academy of Management Journal, 50, 57-84.

Maitlis S. and Sonenshein, S. (2010). Sensemaking in crisis and change: Inspiration and insights from Weick (1988). Journal of Management Studies, 47, 551-580.

Malsch, B., Tremblay, M. S. and Gendron, Y. (2012). Sense-making in compensation committees: A cultural theory perspective. Organization Studies, 33, 389-421.

Mantere, S., Schildt, H. A. and Sillince, J. A. A. (2012). Reversal of strategic change. Academy of Management Journal, 55, 172-196. 
Marshall, N., and Rollinson, J. (2004). Maybe Bacon had a point: the politics of interpretation in collective sensemaking. British Journal of Management, 15, 71-86.

Mautner, G. (2016). Discourse and management: Critical perspectives through the language lens. Macmillan International Higher Education.

McCarthy, I. P., Hannah, D., Pitt, L. F., and McCarthy, J. M. (2020). Confronting indifference toward truth: Dealing with workplace bullshit. Business Horizons, 63, 253-263.

Meziani, N., \& Cabantous, L. (2020). Acting intuition into sense: How film crews make sense with embodied ways of knowing. Journal of Management Studies, 57, 1384-1419.

Mikkelsen, E. N., Gray, B., \& Petersen, A. (2020). Unconscious processes of organizing: Intergroup conflict in mental health care. Journal of Management Studies, 57, 1355-1383.

Mills, A. J. (2006). Sex, Strategy and the Stratosphere: The Gendering of Airline Cultures. London: Palgrave Macmillan.

Mills, A. J. (2008). Getting critical about sensemaking. Barry, D. and Hansen, H, eds. The Sage Handbook of New Perspectives to Organization Studies. London: Sage, 29-30.

Mills, A. J. and Helms Mills, J. H. (2004). When plausibility fails: towards a critical sensemaking perspective on resistance. Thomas, R., Mills, A. J. and Helms Mills, J., eds. Identity Politics at Work: Resisting Gender and Gendered Resistance. London: Routledge, 141-159.

Mills, J. H. (2002). Employment practices and the gendering of Air Canada's culture during its Trans Canada Airlines Days. Culture and Organization, 8, 117-128.

Molotch, H. L., \& Boden, D. (1985). Talking social structure: Discourse, domination and the Watergate hearings. American Sociological Review, 50, 273-288.

Monin, P., Noorderhaven, N., Vaara, E. and Kroon, D. (2013). Giving sense to and making sense of justice in postmerger integration. Academy of Management Journal, 56, 256-284.

O'Connell, C. J. and Mills, A. J. (2003). Making sense of bad news: The media, sensemaking, and organisational crisis. Canadian Journal of Communication, 28, 323-339.

O'Leary, M. and Chia, R. (2007). Epistemes and structures of sensemaking in organisational life. Journal of Management Inquiry, 16, 392-406.

Patriotta, G. (2003). Sensemaking on the shop floor: Narratives of knowledge in organisations. Journal of Management Studies, 40, 349-375.

Patriotta, G. (2016). Cities of noise: Sensemaking, sensemakers, and organized worlds. Academy of Management Review, 41, 557-570.

Patriotta, G., and Brown, A. D. (2011). Sensemaking, metaphors and performance evaluation. Scandinavian Journal of Management, 27, 34-43.

Pautz, H. (2018). Think tanks, Tories and the austerity discourse coalition. Policy and Society, 37, 155-169.

Phillips, N., Lawrence, T. B. and Hardy, C. (2004). Discourse and institutions. Academy of Management Review, 29, 635-652.

Phillips, N., Sewell, G., \& Jaynes, S. 2008. Applying critical discourse studies in strategic management research. Organisational Research Methods, 11(4): 770-789.

Phillips, N. and Oswick, C. (2012). Organisational discourse: Domains, debates, and directions. Academy of Management Annals, 6, 435-481.

Pratt, M. G. (2000). The good, the bad, and the ambivalent: Managing identification among Amway distributors. Administrative Science Quarterly, 45, 456-493.

Rawls, A. W. (2008). Harold Garfinkel, ethnomethodology and workplace studies. Organization 
Studies, 29, 701-732.

Reinecke, J., Ansari, S. (2015). What is a "fair" price? Ethics as sensemaking. Organisation Science, 26, 867-888.

Reisigl, M., Wodak, R. E. (2015). The discourse-historical perspective (DHA). Wodak, R. E., Meyer, M., eds. Methods of Critical Discourse Studies. London: Sage, 23-61.

Rouleau, L. (2005). Micro-practices of strategic sensemaking and sensegiving: How middle managers interpret and sell change every day. Journal of Management Studies, 42, 1413-1441.

Rouleau, L. and Balogun, J. (2011). Middle managers, strategic sensemaking, and discursive competence. Journal of Management Studies, 48, 953-983.

Sandberg, J. and Tsoukas, H. (2015). Making sense of the sensemaking perspective: Its constituents, limitations, and opportunities for further development. Journal of Organizational Behavior, 36(S1), S6-S32.

Sarangi, S. and Slembrouck, S. (1996). Language, Bureaucracy, and Social Control. London: Longman.

Schildt, H., Mantere, S. and Cornelissen, J. (2020). Power in sensemaking processes. Organization Studies, 41, 241-265.

Snow, D. A. and Benford, R. D. (1988). Ideology, frame resonance, and participant mobilization. International Social Movement Research, 1, 197-217.

Sonenshein, S. (2007). The role of construction, intuition, and justification in responding to ethical issues at work: The sensemaking-intuition model. Academy of Management Review, 32, 10221040.

Sonenshein, S. (2009). The emergence of ethical issues during strategic change. Organization Science, 20, 223-239.

Spicer, A. (2017). Business Bullshit. London: Routledge.

Thompson, J. B. (1984). Studies in the Theory of Ideology. Univ of California Press.

Tourish, D., and Hargie, O. (2012). Metaphors of failure and the failures of metaphor: A critical study of root metaphors used by bankers in explaining the banking crisis. Organization Studies, 33, 1045-1069.

Tsoukas, H., Patriotta, G., Sutcliffe, K. M., \& Maitlis, S. (2020). On the way to Ithaka: Commemorating the 50th Anniversary of the Publication of Karl E. Weick's The Social Psychology of Organizing. Journal of Management Studies, 57, 1315-1330.

Vaara, E. (2003). Post-acquisition integration as sensemaking: Glimpses of ambiguity, confusion, hypocrisy, and politicization. Journal of Management Studies, 40, 859-894.

Vaara, E. and Tienari, J. 2008. A discursive perspective on legitimation strategies in MNCs. Academy of Management Review, 33(4), 985-993.

Vaara, E., Tienari, J., Piekkari, R. and Säntti, R. 2005. Language and the circuits of power in a merging multinational corporation. Journal of Management Studies, 42(3), 595-623.

van Dijk, T. A. (1998). Ideology: A Multidisciplinary Approach. London: Sage.

van Dijk, T. A. (2018). Socio-cognitive perspective. The Routledge Handbook of Critical Discourse Studies. London: Routledge.

Van Leeuwen, T. (2008). Discourse and Practice. Oxford: Oxford University Press.

Vlaar, P.W., Van den Bosch, F.A., Volberda, H. W. (2006). Coping with problems of understanding in interorganisational relationships: Using formalization as a means to make sense. Organization Studies, 27, 1617-1638. 
Weick, K. E. (1979) The social psychology of organizing, 2nd edition. Reading, MA: AddisonWesley.

Weick K. E. (1985). Cosmos vs. chaos: Sense and nonsense in electronic contexts. Organization Dynamics, 14, 51-64.

Weick K. E. (1993). The collapse of sensemaking in organisations: The Mann Gulch disaster. Administrative Science Quarterly, 38, 628-652.

Weick K. E. (1995). Sensemaking in Organizations. Thousand Oaks: Sage.

Weick K. E. (2001). Making Sense of the Organization. Malden, MA: Blackwell.

Weick, K. E. (2020). Sensemaking, organizing, and surpassing: A handoff. Journal of Management Studies, 57, 1420-1431.

Weick K. E., Sutcliffe, K.M. and Obstfeld, D. (2005). Organizing and the process of sensemaking. Organization Science, 16, 409-421.

Whittle, A., Mueller, F., Gilchrist, A. and Lenney, P. (2016). Sensemaking, sense-censoring and strategic inaction: The discursive enactment of power and politics in a multinational corporation. Organization Studies, 37, 1232-1351.

Willmott, H. (2013). Reflections on the darker side of conventional power analytics. Academy of Management Perspectives, 27, 281-286.

Wodak, R. 2015. The Politics of Fear: What Right-Wing Populist Discourses Mean. London: Sage. Wodak. R. \& Krzyzanowski, M. 2008. Qualitative Discourse Analysis in the Social Sciences. Palgrave.

Wodak, R. and Meyer, M. (Eds.) (2015). Methods of Critical Discourse Studies. London: Sage.

Wodak, R., Kwon, W. and Clarke, I. (2011). 'Getting people on board': Discursive leadership for consensus building in team meetings. Discourse and Society, 22, 592-644.

Zilber, T. B. (2007). Stories and the discursive dynamics of institutional entrepreneurship: The case of Israeli high-tech after the bubble. Organization Studies, 28, 1035-1054. 


\section{APPENDIX}

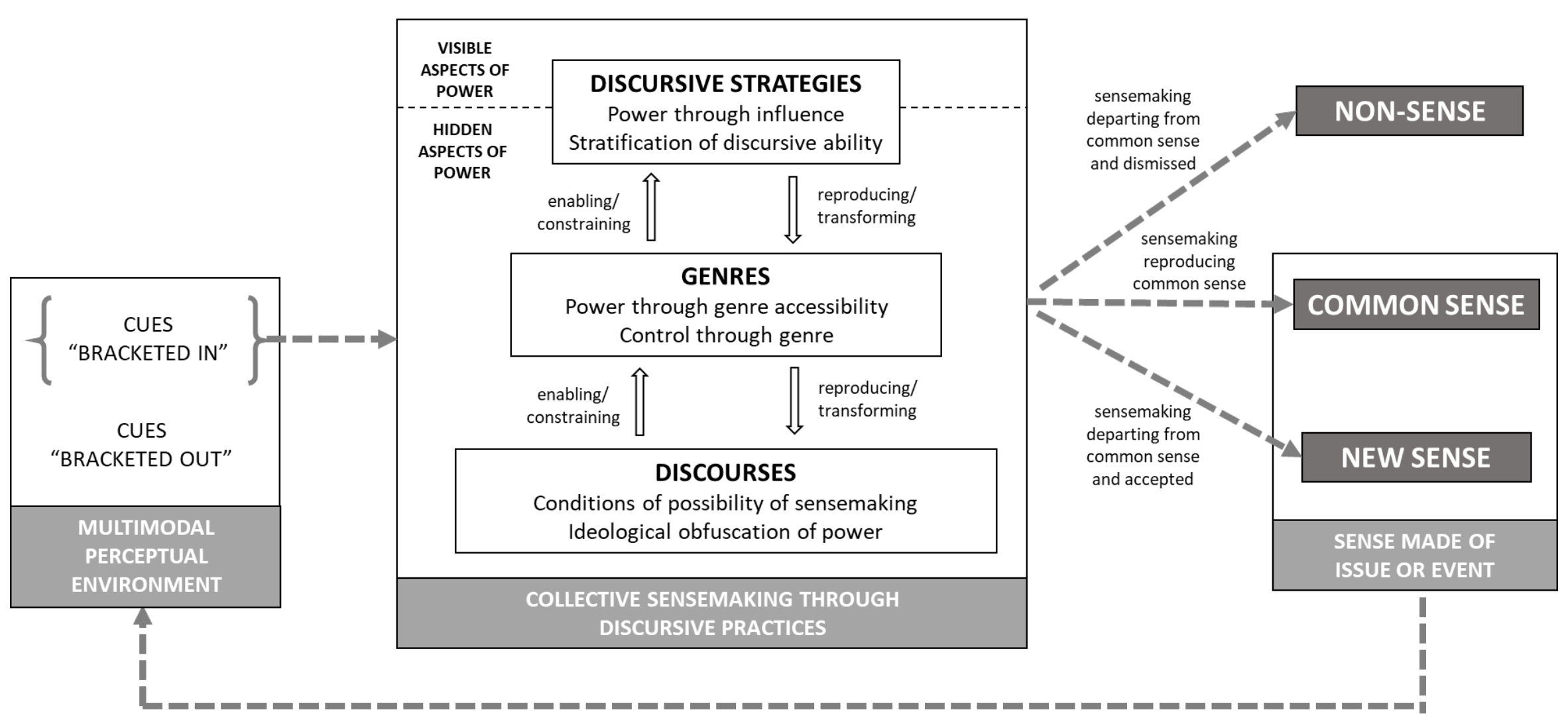

Figure 1 A critical discursive framework for conceptualizing power in collective sensemaking 
Table 1 Three Layers of Exercise of Power in Discursive Sensemaking

\begin{tabular}{|l|l|l|l|}
\hline & Definition & Power implications & Questions for future research \\
\hline $\begin{array}{l}\text { Discursive } \\
\text { strategies }\end{array}$ & $\begin{array}{l}\text { Ways of using available discursive } \\
\text { resources for specific purposes such as to } \\
\text { influence others }\end{array}$ & $\begin{array}{l}\text { Focus on the manifest exercise of } \\
\text { influence over others } \\
\text { More latent aspects of power operate } \\
\text { through the stratification of discursive } \\
\text { ability }\end{array}$ & $\begin{array}{l}\text { How do actors use discursive strategies to } \\
\text { influence others? } \\
\text { the differential ability of actors to produce } \\
\text { discourse that is viewed as legitimate? }\end{array}$ \\
\hline Genres & $\begin{array}{l}\text { A socially recognized and accepted set of } \\
\text { conventions, rules and patterns of } \\
\text { communicative interaction, which are } \\
\text { enacted by social actors in habitual and } \\
\text { often taken for granted ways }\end{array}$ & $\begin{array}{l}\text { Focus on the latent aspect of power } \\
\text { through genres enabling or } \\
\text { constraining sensemaking }\end{array}$ & $\begin{array}{l}\text { How do genres shape who has access to } \\
\text { participate in the discursive practices used in } \\
\text { sensemaking? }\end{array}$ \\
\hline Discourses & $\begin{array}{l}\text { Standardised ways of talking, writing and } \\
\text { thinking about certain types of } \\
\text { phenomena with particular vocabularies }\end{array}$ & $\begin{array}{l}\text { Focus on the latent aspects of } \\
\text { discourses pre-structuring } \\
\text { sensemaking }\end{array}$ & $\begin{array}{l}\text { How do genres act to exercise control, or } \\
\text { shift control, over the sense that emerges? }\end{array}$ \\
& possibility for sensemaking? \\
\hline
\end{tabular}


Table 2. Three outcomes of discursive sensemaking: common sense, new sense and non-sense

\begin{tabular}{|c|c|c|c|}
\hline & Definition & Power implications & Questions for future research \\
\hline Common sense & $\begin{array}{l}\text { A way of making sense of an issue or } \\
\text { situation that is widely taken-for- } \\
\text { granted as natural, obvious or right. }\end{array}$ & $\begin{array}{l}\text { Domination is reproduced and power is } \\
\text { obscured through ideologically-laden } \\
\text { discourses being viewed as neutral or } \\
\text { even beneficial to those dominated. }\end{array}$ & $\begin{array}{l}\text { How does the common sense reproduced } \\
\text { by the social group or organisation } \\
\text { naturalize existing power structures? }\end{array}$ \\
\hline New sense & $\begin{array}{l}\text { The creation of a new way of making } \\
\text { sense of an issue or situation that } \\
\text { departs from common sense. }\end{array}$ & $\begin{array}{l}\text { Domination is contested, challenged or } \\
\text { changed through the creation of new } \\
\text { ways of making sense in a counter- } \\
\text { discourse that disrupts existing power } \\
\text { relations. }\end{array}$ & $\begin{array}{l}\text { How does the new sense created by the } \\
\text { social group or organisation challenge } \\
\text { existing power structures? }\end{array}$ \\
\hline Non-sense & $\begin{array}{l}\text { The dismissal of an alternative way of } \\
\text { making sense of an issue or situation } \\
\text { that departs from common sense. }\end{array}$ & $\begin{array}{l}\text { Domination is reproduced through the } \\
\text { delegitimation of ways of making } \\
\text { sense in discourses that challenge } \\
\text { systems of domination. } \\
\\
\text { At its extreme, absolute hegemonic } \\
\text { dominance of prevailing discourses } \\
\text { render any other way of making sense } \\
\text { 'unintelligible'. }\end{array}$ & $\begin{array}{l}\text { How is the new sense created by the social } \\
\text { group or organisation dismissed in order to } \\
\text { protect existing power structures? } \\
\text { How do dominant discourses render } \\
\text { certain ways of making sense } \\
\text { inconceivable? }\end{array}$ \\
\hline
\end{tabular}

